\author{
Serhii Puhach \\ PhD (Geography), Associate Professor of the Department of Economic and Social Geography \\ e-mail: puhachserhiy@gmail.com, ORCID ID: https://orcid.org/0000-0002-3738-7961 \\ Lesia Ukrainka Eastern European National University, Volya Avenue 13, Lutsk, 43025, Ukraine \\ Taras Pohrebskyi \\ PhD (Geography), Associate Professor of the Department of Economic and Social Geography \\ e-mail: taraspogrebskyi@gmail.com, ORCID ID: https://orcid.org/0000-0002-2290-134X \\ Lesia Ukrainka Eastern European National University, Volya Avenue 13, Lutsk, 43025, Ukraine \\ Gennadii Golub \\ PhD (Geography), Associate Professor of the Department of Economic and Social Geography \\ e-mail: golubgs111@gmail.com, ORCID ID: https://orcid.org/0000-0003-3548-6998 \\ Lesia Ukrainka Eastern European National University, Volya Avenue 13, Lutsk, 43025, Ukraine
}

\title{
SPATIAL PECULIARITIES OF SOCIAL NETWORKING SERVICES DISTRIBUTION IN RIVNENSKA OBLAST
}

Social networking services are a modern phenomenon in the field of human relations. As differentiated from western science, the issue of SNS spatial distribution is not a matter of high concern in Ukrainian researchers because of a number of objective and subjective reasons. The main task of the research is to analyze the spatial distribution of the amount of users and the penetration level of social networking services such as Facebook and Instagram in administrative districts and cities of region subordination belonging to Rivnenska oblast.

Facebook is the most popular social networking service in Rivnenska oblast. There is a trend towards concentration of users' accounts in big cities: Rivne City, Dubno City, Varash City. More than 70\% of users of the oblast live in the cities of oblast subordination and $58.4 \%$ of accounts are concentrated in Rivne City which is also the regional center. T. Hägerstrand's Spatial Innovation Diffusion Theory has been proved - the largest cities of the oblast are regional innovation centers. Densely populated Sarnenskyi, Bereznivskyi, and Kostopilskyi districts are distinguished among the districts. Facebook is the least used in Dubenskyi, Rivnenskyi, Ostrozkyi, Zarichnenskyi, Demydivskyi, Hoshchanskyi districts.

The penetration rate of the social networking service Facebook in the oblast is $32.7 \%$ (in Ukraine $-31.0 \%$ ). The highest level is in cities of oblast subordination. Rivne City and Dubno City are particularly distinguished. High levels of penetration are achieved due to the high development of technical infrastructure, through the companies' and shops' accounts, as well as accounts of residents from surrounding villages. The relatively low penetration rate in Varash City, the second largest city of Rivne oblast due to population, can be explained by the weaker connections with the surrounding area. In administrative districts, the penetration rate is much lower. A relatively high percentage of users are in Radyvylivskyi, Bereznivskyi, Kostopilskyi districts. These districts are characterized by a high level of socio-economic development and convenient socio-geographical location. The lowest level of penetration of the social networking service is in Demydivskyi, Zarichnenskyi, Hoshchanskyi districts. These are little developed and depressed territories within the oblast.

The second most popular social networking service in Rivnenska oblast is Instagram ( $26.3 \%$ penetration rate). In terms of development, it is inferior to Facebook, and its main users are mostly young people. In the spatial distribution of Instagram users, we can trace the same trends as the Facebook.

In general, the distribution of social networking services such as Facebook and Instagram in Rivnenska oblast corresponds to a hierarchical model of spatial diffusion. There is a trend towards concentration of users in big cities.

Keywords: social networking service (SNS), penetration rate of the SNS, Facebook, Instagram, Rivnenska oblast.

Сергій Пугач, Тарас Погребський, Геннадій Голуб. ПРОСТОРОВІ ОСОБЛИВОСТІ ПОНИРЕННЯ СОЦАЛЬНИХ ІНТЕРНЕТ-МЕРЕЖ У РІВНЕНСЬКІЙ ОБЛАСТІ

Соціальні інтернет-мережі є феноменом сьогодення у сфері людських відносин. В українських дослідників, на відміну від західної науки, питання просторового поширення соціальних мереж не викликає значного інтересу, через ряд об'єктивних та суб'єктивних причин. Головне завдання дослідження - проаналізувати просторовий розподіл кількості користувачів та рівень проникнення соціальних Інтернет-мереж Facebook та Instagram у розрізі адміністративних районів та міст обласного підпорядкування Рівненської області.

Facebook $\epsilon$ найпопулярнішою соціальною Інтернет-мережею у Рівненській області. Прослідковується тенденція до концентрації акаунтів у великих містах: Рівне, Дубно, Вараш. На міста обласного підпорядкування припадає понад 70 \% користувачів області, в обласному центрі м. Рівне зосереджено 58,4 \% акаунтів. Підтверджується теорія просторової дифузії нововведень Т. Хегерстранда - найбільші міста області є регіональними центрами інновацій. Серед районів вирізняються густозаселені Сарненський, Березнівський, Костопільський райони. Найменше користуються Facebook у Дубенському, Рівненському, Острозькому, Зарічненському, Демидівському, Гощанському районах.

Рівень проникнення соціальної мережі Facebook в області становить 32,7 \% (в Україні - 31,0 \%). Найвищий він у містах обласного підпорядкування. Особливо вирізняються міста Рівне та Дубно. Високі показники рівня проникнення досягаються внаслідок високого розвитку технічної інфраструктури, за рахунок акаунтів фірм та магазинів, а також мешканців прилеглих сіл.

(C) Puhach S., Pohrebskyi T., Golub G., 2020 
Порівняно низький показник проникнення у м. Вараш - другого за чисельністю населення міста Рівненської області, можна пояснити слабшими зв'язками із навколишньою територією. У адміністративних районах рівень проникнення значно нижчий. Відносно висока частка користувачів прослідковується у Радивилівському, Березнівському, Костопільському районах. Для них характерний високий рівень соціально-економічного розвитку та зручне суспільно-географічне положення. Найнижчий рівень проникнення соціальної інтернет-мережі у Демидівському, Зарічненському, Гощанському районах. Це мало розвинені, депресивні території у межах області.

Другою за популярністю соціальною мережею у Рівненській області $\epsilon$ Instagram (рівень проникнення 26,3%). 3а рівнем розвитку вона поступається Facebook, а іï основними користувачами є переважно особи молодших вікових груп. У просторовому розподілі користувачів Instagram можна простежити ті ж тенденції, що й для мережі Facebook.

Загалом поширення соціальних мереж Facebook та Instagram у Рівненській області відповідає ієрархічній моделі просторової дифузії. Прослідковується тенденція до концентрації користувачів у великих містах.

Ключові слова: соціальна інтернет-мережа, рівень проникнення мережі, Facebook, Instagram, Рівненська область.

Сергей Пугач, Тарас Погребский, Геннадий Голуб. ПРОСТРАНСТВЕННЫЕ ОСОБЕННОСТИ РАСПРОСТРАНЕНИЯ СОЦИАЛЬНЫХ ИНТЕРНЕТ-СЕТЕЙ В РОВЕНСКОЙ ОБЛАСТИ

Социальные интернет-сети является феноменом настоящего в сфере человеческих отношений. В украинских исследователей, в отличие от западной науки, вопросы пространственного распространения социальных сетей не вызывают значительного интереса, по ряду объективных и субъективных причин. Главная задача исследования - проанализировать пространственное распределение количества пользователей и уровень проникновения социальных интернет-сетей Facebook и Instagram в разрезе административных районов и городов областного подчинения Ровенской области.

Facebook является самой популярной социальной интернет-сетью в Ровенской области. Прослеживается тенденция к концентрации аккаунтов в больших городах: Ровно, Дубно, Вараш. На города областного подчинения приходится более $70 \%$ пользователей области, в областном центре г. Ровно сосредоточено 58,4\% аккаунтов. Подтверждается теория пространственной диффузии инноваций Т. Хегерстранда - крупнейшие города области являются региональными центрами инноваций. Среди районов отличаются густонаселенные Сарненский, Березновский, Костопольский районы. Меньше пользуются Facebook в Дубенском, Ровенском, Острожском, Заричненском, Демидовском, Гощанском районах.

Уровень проникновения социальной сети Facebook в области составляет 32,7\% (в Украине - 31,0\%). Самый высокий он в городах областного подчинения. Особенно выделяются города Ровно и Дубно. Высокие показатели уровня проникновения достигаются в результате высокого развития технической инфраструктуры, за счет аккаунтов фирм и магазинов, а также жителей близлежащих сел. Сравнительно низкий показатель проникновения в г. Вараш - второго по численности населения города Ровенской области, можно объяснить слабыми связями с окружающей территорией. В административных районах уровень проникновения значительно ниже. Относительно высокая доля пользователей прослеживается в Радивиловском, Березнивском, Костопольском районах. Для них характерен высокий уровень социально-экономического развития и удобное общественно-географическое положение. Самый низкий уровень проникновения социальной интернет-сети в Демидовском, Заричненском, Гощанском районах. Это слаборазвитые, депрессивные территории в пределах области.

Второй по популярности социальной сетью в Ровенской области является Instagram (уровень проникновения 26,3\%). По уровню развития она уступает Facebook, a еe основными пользователями являются преимущественно лица младшего возраста. В пространственном распределении пользователей Instagram можно проследить те же тенденции, что и для сети Facebook.

В общем распространение социальных сетей Facebook и Instagram в Ровенской области соответствует иерархической модели пространственной диффузии. Прослеживается тенденция к концентрации пользователей в крупных городах.

Ключевые слова: социальная интернет-сеть, уровень проникновения сети, Facebook, Instagram, Ровенская область.

Formulation of the problem in general. Social networking services, the leaders of which are Facebook and Instagram, are current phenomenon in the field of human relations, which is implemented on the basis of the World Wide Web and mobile telephony. It is difficult to imagine the modern life of human society without the various mobile devices that constantly accompany a person and penetrate more and more into the life. There is an opinion that gadgets fundamentally change people. By itself, a mobile device, often a smartphone provides only new opportunities for human communication. One of the prerequisites for expanding human communication is a group of services that in spoken language are called «social networking services». Social networking services have become an integral part of modern life. Business, politics, show business, mass media, entertainment, personal communication of human individuals are increasingly immersed in the world of social networking services.

The person is covered by an information field, which with the advent and widespread of social networking services has significantly expanded. Long distances and national borders have ceased to be an obstacle to the exchange of views between people, the sphere of com- munication has become the whole world. Human communications have reached a new level that has not yet been fully understood by scientists. Nowadays person is remaining in two worlds: the real physical world and the virtual world of social networking services.

However, at present, the studies of spatial aspects of social networking services in Ukraine have not received sufficient attention from scientists, which makes relevant this research.

Analysis of previous researches and publications. The research of social networking services has begun in the USA and European countries. Accordingly, the main achievements are concentrated in English-language scientific literature, mainly sociological. A number of works are devoted to the issues of territorial distribution and spatial aspects of the functioning of social online services. Thus, the theoretical issues of the research of social networking services in terms of human geography are devoted to the works of Ter Wal A., Boschma R. [17] and Glückler J., Doreian P. [5]; the effect of distance on the intensity of communication in social networking services was investigated by Lengyel B., Varga A., Ságvári B., Jakobi Á., Kertész J. [8]; analysis of large-scale geographical patterns resulting of users' in- 
teraction in social networking services are devoted to the works of Menezes T, Roth C. [10] and BorgeHolthoefer J., Rivero A., García I., Cauhé E., Ferrer A., Ferrer D. etc. [2]; the possibility of data integrating from social networking services into GIS was studied by Sui D., Goodchild M. [15] and Andris C. [1]; the influence of geographical distance, national borders, language and frequency of air travel on the formation of social connections in Twitter were considered by Takhteyev Y, Gruzd A, Wellman B. [16]; the link between distance and online engagement on the example of the Spanish social networking service Tuenti were studied by Laniado D., Volkovich Y., Scellato S., Mascolo C., Kaltenbrunner A. [7].

In Ukrainian modern scientific literature the social networking services are mostly investigate by sociologists, which analyzes the phenomenon of social networking services, aspects of their impact on society, some of its age categories (especially children and adolescents), the possibility of using services in political technology, education and more. The geographic researches have not received enough attention to the proliferation of social networking services. To some extent, geographic content have the researches «Review of social networking services and Twitter in Ukraine...» [20], «Facebook and Instagram in Ukraine (September 2019)» [11]. An interesting are the researches of the spatial features of the use of social networking services during the war in eastern Ukraine [3], distribution of social networking services in Volyn oblast [13] and in Ukraine [12].

However, there are no researches of the spatial aspects of the spread of social networking services at the local level in Ukraine. Our research is aimed at overcoming of these gaps.

Research design, methods and data. There are some difficulties with the collection of primary statistical information regarding users of social networking services [13]. We can only talk about the approximate number of social networking service users. To determine the number of Facebook and Instagram users, we used the targeting function - an advertising mechanism that allows to exclude only a portion of your visitors or a target audience that matches your criteria [4]. The criterion we chose was the coverage of the territory.

To do this, we chose "Advertising - Create an Ad Reach - Set Up Ad Account" at our Facebook page. In "Placements" section, "Edit Placements" was selected; only "Facebook" was selected among "Platforms".

In the Audience section, we set the following parameters: "People who live in this location", "Age" from "13" to "65+", "Gender" - "All".

Directly in the map window ("Locations"), the administrative unit was allocated by looking for its name in the case of the region. For districts we used the search by postal codes.

Primary statistics data of the number of social networking service users on the research territory were collected in the first half of February 2020.

In addition to the total number of users, we also used the social networking service penetration rate, which was calculated by the formula:

$$
\text { Psns }_{i}=\left(N_{i} / P_{i}\right) * 100 \%,
$$

where $P s n s_{i}$ - penetration rate of the SNS in the iterritory; \%; $N_{i}$ - number of users SNS in the i-territory, thous. people; $P_{i}$ - population of i-territory, thous. people.

The population for October 1, 2019 was taken from the site of Main department of statistics in Rivnenska oblast of State Statistics Service of Ukraine [9].

Formulating the purpose of the article. The purpose of this research is to identify the features of spatial differentiation of social networking services in Rivnenska oblast. The main task of the work is to analyze the spatial distribution of the number of users and the level of penetration of social networking services Facebook and Instagram by administrative districts and cities of oblast subordination of Rivnenska oblast.

Results and discussion. Rivnenska oblast is the territory in the north-west part of Ukraine, bordering with the Volynska oblast in the west, with the Republic of Belarus - in the north, Zhytomyrska oblast - in the east, Khmelnytska oblast - in the south-east, Ternopilska oblast - in the south, and Lvivska oblast - in the southwest. The oblast is characterized by borderline and transit geographical position, low level of urbanization and average level of socio-economic development.

Originally developed as a means of communication between Harvard students, Facebook is a social service that has gained immense popularity and is now the largest social networking service in the world. According to official statistics, more than 2.45 billion people have already registered their accounts there [21]. Almost every major company or firm, especially those entering the international market, considers it their duty to establish a representative office on Facebook.

Facebook is one of the most popular social media sites in Ukraine. The average monthly audience of the network in Ukraine is 14.0 million users [4], which is $33.4 \%$ of the country's population (as of early 2020). In Rivnenska oblast, there are 376,.8 thousand Facebook users, representing $32.7 \%$ of the population of the region and $2.7 \%$ of all Ukrainian users of the network (the share of the region in the country's population is $2.8 \%$ ). That is, the level of penetration of the Facebook in the Rivnenska oblast corresponds to the average Ukrainian indicators.

The territorial differentiation of Facebook users by districts and major cities of Rivnenska oblast shows the regularity of concentration of the prevailing number of accounts in the largest cities: Rivne City (220 thous.), Dubno City (27 thous.), Varash City (15 thous.) (Table 1, Fig. 1). The four cities of regional subordination including Ostroh City (7.1 thous.) account for $71.4 \%$ of users of the region. $58.4 \%$ of accounts are concentrated in the regional center - Rivne City. This is a pretty high value. In Western Ukraine it is higher only in Chernivetska $(81.6 \%)$ and Lvivska $(62.6 \%)$ oblasts. That is, Rivnenska oblast is characterized by high concentration of population and economy in the regional center, which imprints on the behavior of users on social networking service. This finding is in line with other studies, including the significant predominance of the Internet in large metropolitan areas [19]. Rivnenska oblast has a low level of urbanization (47.5\%). In many villages, especially in the northern Polissya region, there is no wired internet, 
and the signal quality of the mobile operators does not allow the use of social networks. Therefore, a hierarchical model of spatial diffusion of cultural innovation can be clearly observed when the largest cities in the territory are regional centers of innovation.

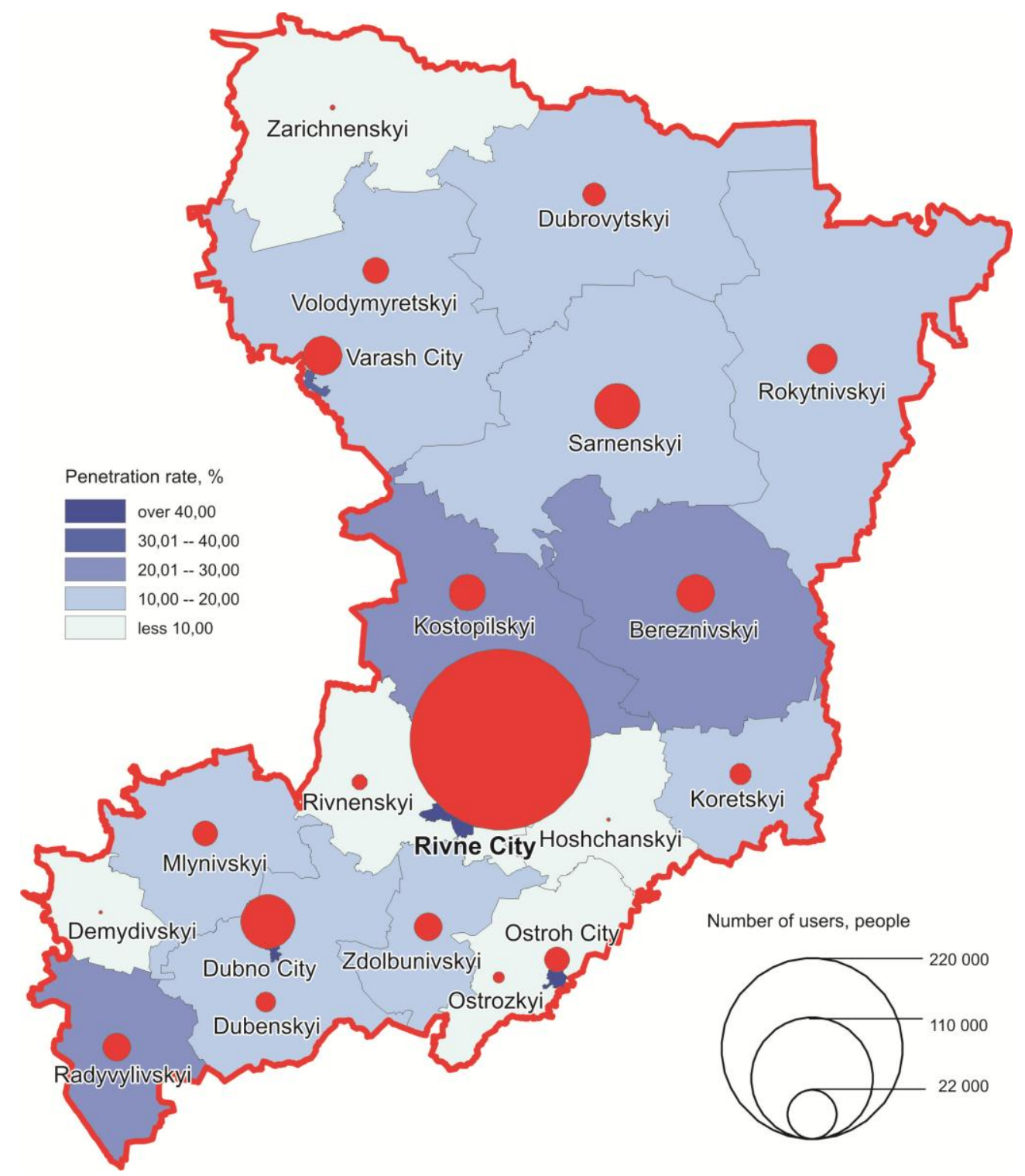

Fig. 1. The number of users and penetration rate of the Facebook SNS in Rivnenska oblast at the beginning of 2020

Densely populated Sarnenskyi, Bereznivskyi, and Kostopilskyi districts are allocated among the districts of Rivnenska oblast by the number of users (over 10 thous. people). The smallest number of people (less than 5 thous. people) use Facebook in Dubenskyi, Rivnenskyi, Ostrozkyi, Zarichnenskyi, Demydivskyi, Hoshchanskyi districts. These districts (except Rivnenskyi) are characterized by a small population. Ostrozkyi and Demydivskyi are the least populated areas in Rivnenska oblast. The low number of users in the Zarichnenskyi district is explained by its peripheral position and low level of socio-economic development.

An important indicator that characterizes the spread of the service is the level of penetration of the social networking service, which is calculated as the ratio of the number of users in a certain area to the population that lives on it. According to the penetration rate of the social media, cities of regional subordination (over 35\%) are distinguished. The highest values were observed in the regional center - Rivne City $-89.4 \%$ and Dubno City $-72.0 \%$ (Table 1). Such high rates are achieved both due to the population of the city registered on the social networking service and at the expense of accounts from various companies and stores. Urban users are also residents of surrounding villages. These villages form a single settlement system with the city near which they are located.

The relatively low penetration rate in the Varash City $(35.5 \%)$ - the "the city of the atomists", the second largest population of the city in Rivnenska oblast, can be explained by its weaker links with the surrounding area. In other words, there is no cluster of rural settlements 
around Varash City, which are economically, socially and culturally related to it and form a single settlement system. Varash City is not the center of the administrative district, which "attracts" the population with administrative functions. All this affects the number of active users of the social media. In Volynska oblast a similar situation is observed in the mining town - Novovolynsk, which is also loosely connected with the surrounding area.

The level of penetration of the social networking service Facebook into the administrative districts of the oblast is much lower and does not exceed 23\%. A relatively high proportion of network users (more than 20\%) were recorded in the Radyvylivskyi, Bereznivskyi, and Kostopilskyi districts. They are characterized by a rela- tively high level of socio-economic development and convenient socio-geographical location.

A low share of users (less than $11 \%$ ) is noted in Dubenskyi, Ostrozkyi, Rivnenskyi, Demydivskyi, Zarichnenskyi, Hoshchanskyi districts. Geographically, it is mainly the central and southern part of the region. Dubenskyi, Ostrozkyi, Rivnenskyi - these are the areas adjacent to the cities of regional subordination. They are characterized by an increased proportion of the rural population and a concentration of socio-economic and political life in the Dubno City, Ostroh City and Rivne City, which are not territorially related to them. The cities of regional subordination seem to "pull" social media users out of the area.

Table 1

\section{The main indicators of Facebook and Instagram social networking services distribution in Rivnenska oblast, at the beginning of 2020*}

\begin{tabular}{|c|c|c|c|c|c|c|}
\hline \multirow[b]{2}{*}{ № } & \multirow[b]{2}{*}{$\begin{array}{l}\text { City of oblast subordi- } \\
\text { nation / district }\end{array}$} & \multirow[b]{2}{*}{$\begin{array}{l}\text { Population, per- } \\
\text { sons } \\
\text { (as of } 1.10 .19 \text { ) }\end{array}$} & \multicolumn{2}{|c|}{ Facebook } & \multicolumn{2}{|c|}{ Instagram } \\
\hline & & & 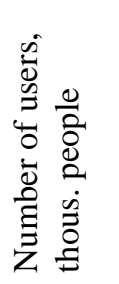 & 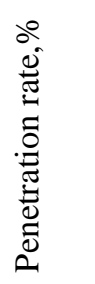 & 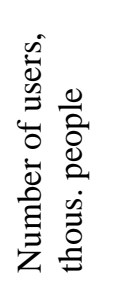 & 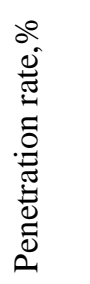 \\
\hline 1 & Rivne City & 246101 & 220.0 & 89.4 & 160.0 & 65.0 \\
\hline 2 & Dubno City & 37510 & 27.0 & 72.0 & 18.0 & 48.0 \\
\hline 3 & Varash City & 42236 & 15.0 & 35.5 & 11.0 & 26.0 \\
\hline 4 & Ostroh City & 15461 & 7.1 & 45.9 & 5.0 & 32.3 \\
\hline 5 & Bereznivskyi & 63745 & 14.0 & 22.0 & 15.0 & 23.5 \\
\hline 6 & Volodymyretskyi & 65483 & 7.5 & 11.5 & 8.5 & 13.0 \\
\hline 7 & Hoshchanskyi & 34468 & 0.2 & 0.6 & 1.1 & 3.2 \\
\hline 8 & Demydivskyi & 14082 & 0.3 & 2.1 & 0.6 & 4.3 \\
\hline 9 & Dubenskyi & 44428 & 4.8 & 10.8 & 5.1 & 11.5 \\
\hline 10 & Dubrovytskyi & 46817 & 5.8 & 12.4 & 6.0 & 12.8 \\
\hline 11 & Zarichnenskyi & 34759 & 0.4 & 1.2 & 1.6 & 4.6 \\
\hline 12 & Zdolbunivskyi & 56169 & 8.2 & 14.6 & 7.1 & 12.6 \\
\hline 13 & Koretskyi & 32643 & 5.0 & 15.3 & 3.8 & 11.6 \\
\hline 14 & Kostopilskyi & 63517 & 13.0 & 20.5 & 10.0 & 15.7 \\
\hline 15 & Mlynivskyi & 36841 & 6.9 & 18.7 & 5.0 & 13.6 \\
\hline 16 & Ostrozkyi & 27808 & 1.8 & 6.5 & 1.3 & 4.7 \\
\hline 17 & Radyvylivskyi & 36493 & 8.4 & 23.0 & 6.8 & 18.6 \\
\hline 18 & Rivnenskyi & 92869 & 2.9 & 3.1 & 7.2 & 7.8 \\
\hline 19 & Rokytnivskyi & 58180 & 9.5 & 16.3 & 11.0 & 18.9 \\
\hline \multirow[t]{2}{*}{20} & Sarnenskyi & 104092 & 19.0 & 18.3 & 19.0 & 18.3 \\
\hline & Rivnenska oblast & 1153702 & 376.8 & 32.7 & 303.1 & 26.3 \\
\hline
\end{tabular}

Particularly low rate of penetration of the social networking service (less than 3\%) in Demydivskyi, Zarichnenskyi, Hoshchanskyi districts (Table 1, Fig. 1). It had developed, depressed territories within the oblast. Zarichnenskyi district is characterized by peripherality and unfavorable socio-geographical position. Demydivskyi district has the smallest area and the lowest population in the Rivne region, which imposes a certain imprint on socio-economic processes.
In the Rivnenska oblast, the penetration rate of the social media Facebook for administrative districts is on average $12.3 \%$, the cities of regional subordination $60.7 \%$, with the average regional $32.7 \%$. This reaffirms the unequal distribution of users in urban and rural areas and the role of major cities as centers of innovation.

Instagram is a social online photo and video sharing media that allows users to take photos and videos, apply filters to them, and distribute them. The total number of 
users of this network is over 1 billion [14]. In Ukraine its average monthly audience are more than 11.0 million users [4], which is $26.2 \%$ of the country's population (as of early 2020).

In the Rivnenska oblast there are 303.1 thousand Instagram users [4], which is $26.3 \%$ of the population of the region. The percentage of users from Rivnenska oblast is $2.8 \%$ of all Ukrainian network users, which corresponds to the share of the region in the total population of Ukraine.

The territorial location of Instagram users shows the same features that are typical of Facebook (Table 1, Fig. 2), namely the concentration of most accounts in major cities. Thus, in Rivne City there are 160 thousand users, in Dubno City - 18 thous., in Varash City - 11 thous., in Ostroh City - 5 thous. users. The largest cities account for $64.0 \%$ of users, in Rivne City - 52.8\%. Among administrative districts by number of users the largest population is Sarnenskyi district, and other northern and central densely populated Bereznivskyi, Rokytnivskyi and Kostopilskyi districts (Table 1).

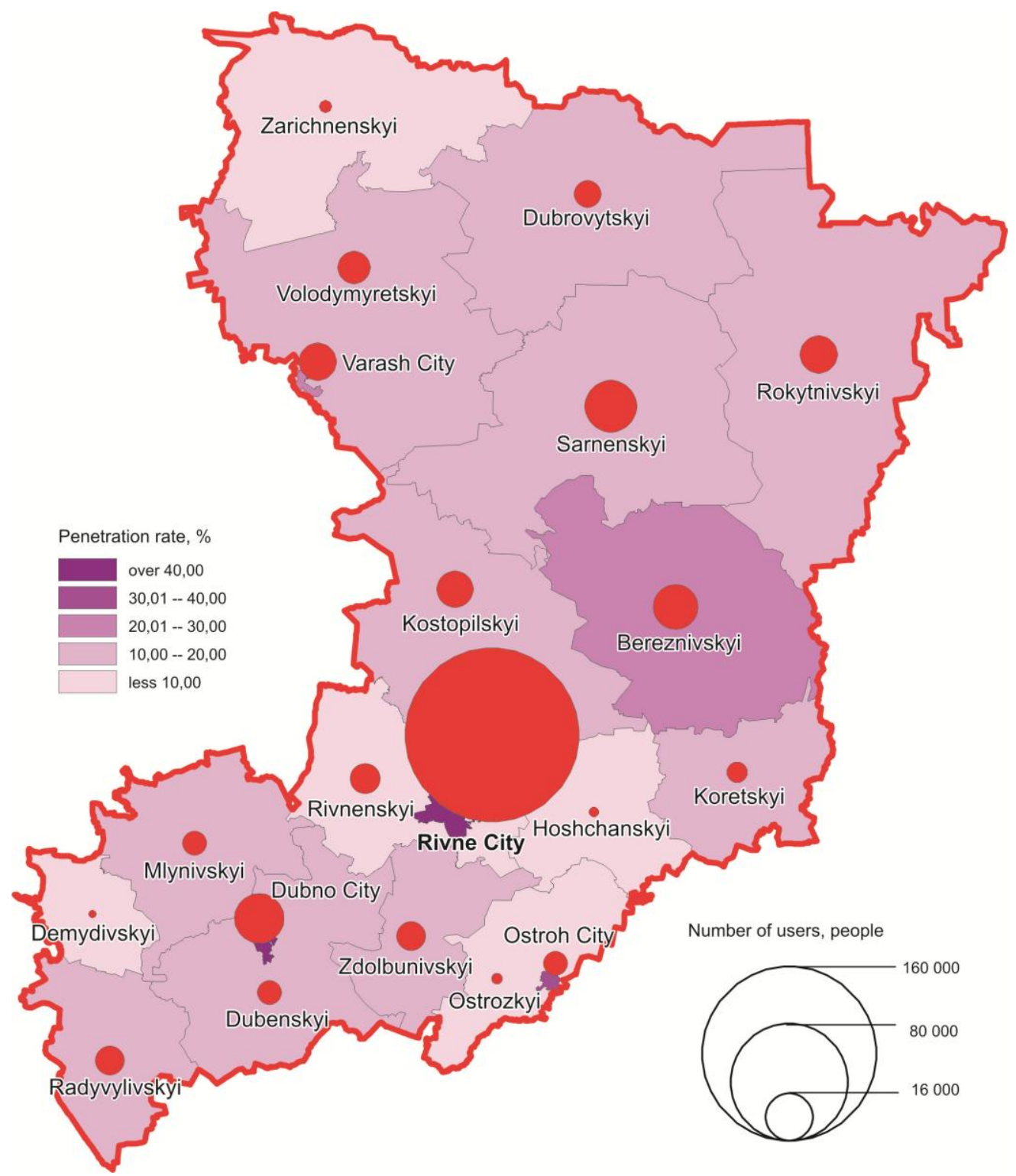

Fig. 2. The number of users and the penetration rate of the Instagram SNS in Rivnenska oblast at the beginning of 2020

In terms of network penetration, the leading positions are occupied by the cities of regional subordination: Rivne City (65.0\%), Dubno City (48.0\%), Ostroh City (32.3\%), Varash City (26.0\%). It draws attention to the relatively low level of Instagram penetration in $\mathrm{Va}$ rash City, what was said earlier. Among the administrative districts are Bereznivskyi, Rokytnivskyi, Radyvylivskyi, Sarnenskyi districts (over 18\%). Kostopilskyi,
Mlynivskyi, Volodymyretskyi, Dubrovytskyi, Zdolbunivskyi, Koretskyi and Dubenskyi districts also have relatively high penetration rates $(10-16 \%)$. The lowest share of users (less than 8\%) was recorded in Rivnenskyi, Ostrozkyi, Zarichnenskyi, Demydivskyi and Hoshchanskyi districts (Table 1, Fig. 2).

For the administrative districts of Rivnenska oblast, the penetration rate of the social media Instagram is on 
average $12.2 \%$, for the cities of regional subordination $42.8 \%$, with the average regional $26.3 \%$.

So, by social development level, Instagram social networking service is inferior to Facebook, and its main users are mostly younger people.

Conclusions and prospects for further researches. Based on the above, we can draw the following conclusions about the general patterns of spatial distribution of social networking services such as Facebook and Instagram in Rivnenska oblast:

- the concentration of users in big cities, especially in the regional center of Rivne City, which accounts more than half of Facebook and Instagram users in the oblast;

- the number of users is generally proportional to the population in the territorial unit;
- low number of users and low level of penetration in administrative districts adjacent to the cities of oblast subordination;

- among the administrative districts, the higher rates of development of social networking services are character for the northern districts compared to the southern ones.

Further researches of the spatial distribution of social networking services should focus on analyzing its dependence on the characteristics of age, gender, ethnic structure and other social categories. The research of the extension of major networks at the administrative district level should be undertaken. The research of the dynamics of social networking services penetration into the rural areas is promising.

\section{References:}

1. Andris, C. (2016). Integrating social network data into GISystems. International Journal of Geographical Information Science, 30:10, 2009-2031.

2. Borge-Holthoefer, J., Rivero, A., García, I., Cauhé, E., Ferrer, A., Ferrer, D. et. al. (2011). Structural and dynamical patterns on online social networks: the Spanish may 15th movement as a case study. PloS ONE, 6(8), e23883. https://doi.org/10.1371/journal.pone.0023883.

3. Dobysh, M. (2019). Euromaidan and conflict in Eastern Ukraine in social networking sites: Territorial differences of pro-Russian subscriptions in Ukraine. Hungarian Geographical Bulletin, 68(1), 51-64. https://doi.org/10.15201/hungeobull.68.1.4.

4. Facebook (2020). Site. facebook.com. Retrieved from https://www.facebook.com.

5. Glückler, J., \& Doreian, P. (2016). Editorial: social network analysis and economic geography - positional, evolutionary and multi-level approaches. Journal of Economic Geography, 16, 6, 1123-1134.

6. Hägerstrand, T. (1967). Innovation diffusion as a spatial process. Chicago: Chicago Press.

7. Laniado, D., Volkovich, Y., Scellato, S., Mascolo, C., \& Kaltenbrunner, A. (2017). The impact of geographic distance on online social interactions. Information Systems Frontiers, 20, 6, 1203-1218. http://doi.org/10.1007/s10796017-9784-9.

8. Lengyel, B., Varga, A., Ságvári, B., Jakobi, Á., Kertész, J., \& Lengyel B. (2015). Geographies of an Online Social Network. PLoS ONE, 10(9), e0137248. https://doi.org/10.1371/journal.pone.0137248.

9. Main Department of Statistics in Rivne region (2020). Chyselnist naselennia (za otsinkoyu) na 1 zhovtnya 2019 roku ta serednya chyselnist u 2019 rotsi [The population (estimated) on October 1, 2019 and the average population in 2019]. Holovne upravlinnia statystyky u Rivnenskii oblasti-Main Department of Statistics in Rivne region. Retrieved from http://www.gusrv.gov.ua [in Ukrainian].

10. Menezes, T., \& Roth, C. (2017). Natural Scales in Geographical Patterns. Scientific Reports, 7 , e45823. https://doi.org/10.1038/srep45823.

11. PlusOne (2019). Facebook ta Instagram v Ukraini (veresen 2019) [Facebook and Instagram in Ukraine (September 2019)]. plusone.com.ua. Retrieved from https://plusone.com.ua/research/Facebook\%20та\%20Instagram\%20в\%20 Україні \%20(вересень\%202019)_.pdf [in Ukrainian].

12. Puhach, S., \& Mytchyk Yu. (2017). Geografiya poshyrennya sotsialnykh merezh v Ukraini [Geography of social networking services in Ukraine]. Proceedings from: Mizhnarodna naukovo-praktychna Internet-konferentsiya "Suspilno-geografichni chynnyky rozvytku regioniv" - International scientific and practical Internet conference "Human geographical factors of regional development". (pp. 99-101). Lutsk: PP Ivanyuk V.P. Retrieved from https://konfgeolutsk.files.wordpress.com/2016/11/zbirnyk_sg_chynnyky.pdf [in Ukrainian].

13. Puhach, S., \& Mytchyk, Yu. (2018). Prostorovyi analiz sotsialnykh internet-merezh u Volynskiy oblasti [Spatial analysis of social networking services in the Volyn region]. Ekonomichna ta sotsialna geografiya - Economic and social geography, 79, 14-21 [in Ukrainian]. https://doi.org/10.17721/2413-7154/2018.79.14-21.

14. Statista (2019). Most popular social networks worldwide as of October 2019, ranked by number of active users (in millions). statista.com. Retrieved from https://www.statista.com/statistics/272014/global-social-networks-rankedby-number-of-user.

15. Sui, D., \& Goodchild, M. (2011). The convergence of GIS and social media: challenges for GIScience. International Journal of Geographical Information Science, 25:11, 1737-1748. https://doi.org/10.1080/13658816.2011.604636.

16. Takhteyev, Y., Gruzd, A., \& Wellman B. (2012). Geography of Twitter networks. Social Networks, 34(1), 73-81. https://doi.org/10.1016/j.socnet.2011.05.006.

17. Ter Wal, A., \& Boschma, R. (2009). Applying social network analysis in economic geography: framing some key analytic issues. The Annals of Regional Science, 43, 3, 739-756. https://doi.org/10.1007/s00168-008-0258-3.

18. Tranos, E. (2013). The Geography of the Internet. Cities, Regions and Internet Infrastructure in Europe (New Horizons in Regional Science Series). Cheltenham: Edward Elgar. 
19. Warf, B. (2017). Alternative Geographies of Cyberspace. In U. Kohl (ed.) The Net and the Nation State. Multidisciplinary Perspectives on Internet Governance. (pp. 147-164). Cambridge: University Press.

20. Yandex (2014). Ohlyad sotsialnykh merezh i Tvittera v Ukraini za danymy Poshuku u blohakh Yandeksa, 20132014 roky [Review of Social Networking Services and Twitter in Ukraine according to Yandex Blog Search, 20132014]. yandex.net. Retrieved from https://cache-man01i.cdn.yandex.net/download.yandex.ru/company/Yandex_on_ UkrainianSMM_Summer_2014.pdf [in Ukrainian].

21.Zephoria (2019). The Top 20 Valuable Facebook Statistics - Updated November 2019. zephoria.com. Retrieved from https://zephoria.com/top-15-valuable-facebook-statistics.

Надійшла до редколегї 21.04.2020 p.

\section{Про авторів:}

Сергій Пугач - кандидат географічних наук, доцент кафедри економічної та соціальної географії, Східноєвропейський національний університет імені Лесі Українки, просп. Волі, 13, м. Луцьк, 43025, Україна, puhachserhiy@gmail.com, https://orcid.org/0000-0002-3738-7961

Тарас Погребський - кандидат географічних наук, доцент кафедри економічної та соціальної географії, Східноєвропейський національний університет імені Лесі Українки, просп. Волі, 13, м. Луцьк, 43025, Україна, taraspogrebskyi@gmail.com, https://orcid.org/0000-0002-2290-134X

Геннадій Голуб - кандидат географічних наук, доцент кафедри економічної та соціальної географії, Східноєвропейський національний університет імені Лесі Українки, просп. Волі, 13, м. Луцьк, 43025, Україна, golubgs111@gmail.com, https://orcid.org/0000-0003-3548-6998

\section{Об авторах:}

Сергей Пугач - кандидат географических наук, доцент кафедры экономической и социальной географии, Восточноевропейский национальный университет имени Леси Украинки, просп. Воли, 13, г. Луцк, 43025, Украина, puhachserhiy@gmail.com, https://orcid.org/0000-0002-3738-7961

Тарас Погребский - кандидат географических наук, доцент кафедры экономической и социальной географии, Восточноевропейский национальный университет имени Леси Украинки, просп. Воли, 13, г. Луцк, 43025, Украина, taraspogrebskyi@gmail.com, https://orcid.org/0000-0002-2290-134X

Геннадий Голуб - кандидат географических наук, доцент кафедры экономической и социальной географии, Восточноевропейский национальный университет имени Леси Украинки, просп. Воли, 13, г. Луцк, 43025, Украина, golubgs111@gmail.com, https://orcid.org/0000-0003-3548-6998 